慶應義塾大学学術情報リポジトリ

Keio Associated Repository of Academic resouces

\begin{tabular}{|c|l|}
\hline Title & $\begin{array}{l}\text { Regional differences in extracellular choline dependency of acetylcholine synthesis in the rat } \\
\text { brain }\end{array}$ \\
\hline Sub Title & \\
\hline Author & $\begin{array}{l}\text { 鈴木, 岳之(Suzuki, Takeshi) } \\
\text { 鹿島, 裕子(Kashima, Yuko) } \\
\text { 藤本, 和子(Fujimoto, Kazuko) } \\
\text { 大畑, 尚代(Ohata, Hisayo) } \\
\text { 川島, 紘一郎(Kawashima, Koichiro) }\end{array}$ \\
\hline Publisher & 共立薬科大学 \\
\hline Publication year & 1991 \\
\hline Jtitle & $\begin{array}{l}\text { 共立薬科大学研究年報 (The annual report of the Kyoritsu College of } \\
\text { Pharmacy). No.36 (1991. ),p.49-49 }\end{array}$ \\
\hline JaLC DOI & \\
\hline Abstract & \\
\hline Notes & 抄録 \\
\hline Genre & Technical Report \\
\hline URL & $\begin{array}{l}\text { https://koara.lib.keio.ac.jp/xoonips/modules/xoonips/detail.php?koara_id=AN00062898-0000003 } \\
6-0049\end{array}$ \\
\hline
\end{tabular}

慶應義塾大学学術情報リポジトリ(KOARA)に掲載されているコンテンツの著作権は、それぞれの著作者、学会または出版社/発行者に帰属し、その権利は著作権法によって 保護されています。引用にあたっては、著作権法を遵守してご利用ください。

The copyrights of content available on the KeiO Associated Repository of Academic resources (KOARA) belong to the respective authors, academic societies, or publishers/issuers, and these rights are protected by the Japanese Copyright Act. When quoting the content, please follow the Japanese copyright act. 


\title{
Regional differences in extracellular choline dependency of acetylcholine synthesis in the rat brain*
}

\author{
Takeshi Suzuki, Yuko Kashima, Kazuko Fujimoto, Hisayo Oohata \\ and Koichiro KaWASHIMA
}

鈴木岳之，鹿島裕子，藤本和子，大畑尚代，川島紘一郎，

Acetylcholine $(\mathrm{ACh})$ synthesis under conditions of restricted extracellular choline uptake was investigated in order to clarify the procurement of choline for $\mathrm{ACh}$ synthesis using slices of several regions of the rat brain. Extracellular choline-independent $\mathrm{ACh}$ synthesis was observed in the hippocampus, frontal cortex and caudate putamen, which contain cholinergic nerve terminals, whereas little or no synthesis was observed in the medial septum or basal nucleus of Meynert, which contain cholinergic cell bodies. These results indicate that cholinergic nerve terminals, but not the cell bodies, may be able to synthesize choline for $\mathrm{ACh}$ biosynthesis. Extracellular choline-dependent $\mathrm{ACh}$ synthesis was observed in all regions examined. In the presence of $10 \mu \mathrm{M}$ choline, the highest content of newly synthesized $\mathrm{ACh}$ and the proportionate increase in $\mathrm{ACh}$ compared with the unreleasable fraction (basal level) were observed in the caudate putamen. In the frontal cortex, although the level of synthesized ACh was low, the proportionate increase in ACh was high. In contrast, in the medial septum and basal nucleus of Meynert, high levels of $\mathrm{ACh}$ with a low proportionate increase compared with basal levels were observed. In the presence of hemicholinium-3, extracellular choline was also taken up for ACh synthesis in all regions examined, the level being especially high in the frontal cortex and medial septum. The present results indicate that the manner of choline procurement for $\mathrm{ACh}$ synthesis is heterogeneous among the various regions of the rat brain.

* 本報告は Neuroscience Research, 11 71一76（1991）に発表. 